XIV Российская национальная конференция по сейсмостойкому строительству и сейсмическому районированию (с международным участием). Сборник материалов

УДК 624.1

DOI 10.37153/2687-0045-2021-14-149-151

\title{
КОНСТРУКТИВНЫЕ МЕРОПРИЯТИЯ ПО ОБЕСПЕЧЕНИЮ УСТОЙЧИВОСТИ АЭС ПРИ СЕЙСМИЧЕСКОМ ВОЗДЕЙСТВИИ
}

\section{STRUCTURAL MEASURES TO ENSURE THE GLOBAL STABILITY OF NPP UNDER SEISMIC IMPACT}

Юрченко Д.А., инженер-проектировщик 1 категории, АО «Атомпроект» Yurchenko D.A., design engineer category 1, JSC “Atomproekt”

Аннотация: B статье рассмотрены варианты компенсирующих конструктивных мероприятий при потере глобальной устойчивости сооружений АЭС, выполненные на основе европейской нормативной документации.

Ключевые слова: глобальная устойчивость, сейсмостойкость, АЭС, global stability, seismic resistance, NPP

Согласно MSZ EN 1990:2011 в проекте сооружения АЭС рассматриваются три гипотетические схемы потери устойчивости:

- Сдвиг (EQU).

- Опрокидывание (EQU).

- Всплытие (UPL).

Расчет производится согласно MSZ EN 1997-1 простой статической оценкой стабилизирующих и дестабилизирующих воздействий в различных расчетных ситуациях: при НУЭ и при внешних аварийных событиях (землетрясение, воздушная ударная волна, удар летящего тела и падение самолета).

Для классической компоновки железобетонного монолитного сооружения с фундаментной плитой и внешними несущими стенами существуют три фактора стабилизирующих воздействий:

1. Собственный вес здания.

2. Сила трения по подошве фундамента.

3. Пассивное давление грунта обратной засыпки.

Конструктивные мероприятия по обеспечению устойчивости здания применяются в случае превышения внешних воздействий над обычными стабилизирующими факторами.

В проекте АЭС рассматривалась возможность применения пяти типов компенсирующих конструктивных мероприятий, обеспечивающих устойчивость сооружения. Данные конструктивные решения носят локальный характер и не имеют влияния ни на генплан АЭС, ни на компоновку технологических систем внутри сооружений, ни на объемно-планировочные решения примыкающих зданий. \section{бетону}

1. Применение гидроизоляции с повышенным коэффициентом трения по

В соответствии с главой C11.2 ASCE 4-16 возможный диапазон коэффициента трения составляет от 0.3 до 0.7. Для обеспечения повышенной сдвиговой устойчивости 
XIV Российская национальная конференция по сейсмостойкому строительству и сейсмическому районированию (с международным участием). Сборник материалов

сооружения допускается применение рулонной гидроизоляции с повышенным коэффициентом трения по бетонной поверхности $(\mu=0.6)$, сертифицированной для строительства АЭС на территории реализации проекта.

\section{2. Устройство кессонных (сдвиговых) стен или зацепной системы фундамент - подбетонка в виде железобетонных зубьев}

Данное конструктивное решение аналогично тому, что применяется при проектировании гидротехнических сооружений (например, дамбы или береговые сооружения). Конструктивное мероприятие допустимо применять для сооружений, покоящихся на подбетонке или укрепленном грунте, теряющих устойчивость по схеме «сдвиг».

Несущая способность узла кессонной стены для каждого сооружения рассчитывается по нормам EN 1992-1-1 с учетом проверки прочности стены на срез и проверки укрепленного грунта или подбетонки на смятие.

\section{3. Увеличение толщины фундаментной плиты}

Решение допустимо применять для сооружений, имеющих высокий потенциал потери устойчивости при сейсмическом воздействии по схеме «опрокидывание» и «всплытие».

Расчет требуемой толщины фундаментной плиты производится по результатам простой статической оценки стабилизирующих и дестабилизирующих воздействий для каждого конкретного сооружения.

\section{4. Использование грунта обратной засыпки с заданными свойствами}

Допускается устанавливать требования к характеристикам грунта обратной засыпки, обеспечивающим максимальные значения пассивного сейсмического отпора грунта. Техническое решение применяется для заглубленных в грунт сооружений, имеющих высокий потенциал потери устойчивости по схеме «сдвиг» при сейсмическом воздействии.

При выборе грунтового материала для обратной засыпки на этапе рабочего проектирования необходимо, чтобы его реальные характеристики обеспечивали минимальные значения активного сейсмического давления грунта и максимальные значения пассивного сейсмического отпора грунта.

В первую очередь это может быть достигнуто за счет использования для обратной засыпки грунта с большим коэффициентом внутреннего трения по сравнению с заложенным в расчет.

Окончательный выбор грунта обратной засыпки с целью обеспечить наилучшее взаимодействие грунта и подземного сооружения в условиях сейсмического воздействия высокой интенсивности должен быть сделан на основании сопоставительных расчетов по результатам исследования свойств, имеющихся в наличии и потенциально пригодных для обратной засыпки грунтов.

Производство работ и контроль за ними должны обеспечивать получение обратных засыпок надлежащего качества.

\section{5. Частичное увеличение ширины фундаментной плиты}

Решение допустимо применять для сооружений, имеющих высокий потенциал потери устойчивости при сейсмическом воздействии по схеме «опрокидывание». 
XIV Российская национальная конференция по сейсмостойкому строительству и сейсмическому районированию (с международным участием). Сборник материалов

Размеры фундаментной плиты рассчитываются на основе простой статической оценки стабилизирующих и дестабилизирующих воздействий для каждого конкретного сооружения.

\section{Заключение}

По результатам проработки данных конструктивных решений удалось внести изменения в конструктив зданий и сооружений АЭС, где были выявлены проблемы с обеспечением глобальной устойчивости. Данные решения прошли экспертизу заказчика и планируются к реализации при строительстве АЭС.

\section{Список литературы}

1. Бирбраер А.Н. Расчет конструкций на сейсмостойкость. - СПб: Наука, 1998.

2. Иванов П.Л. Грунты и основания гидротехнических сооружений. - М.: Высш. шк., 1985.

3. ASCE/SEI 4-16, Seismic analysis of safety - related nuclear structures. Reston, Viginia, ASCE, 2017.

4. EN 1992-1-1, Eurocode 2: Design of concrete structures - Part 1-1: General rules and rules for buildings. Brussels, CEN, 2004.

5. EN 1997-1, Eurocode 7: Geotechnical design - Part 1: General rules. Brussels, CEN, 2004. 